\title{
A Gathering STORM: WATER CONFLICT IN ALBERTA
}

\author{
RANDALL W. BLOCK AND JOEL FORREST
}

This article explores water conflict in Alberta. It discusses new allocation requirements, legislative issues with the relatively nely Water Act and the general legal backdrop to water conflict. There is then a focus on recent examples where legal enillement was raised, but not definitely resolved.
Cet arficle explore les litiges relatifs aux eaux en Alberia. II porte aussi sur les nouvelles exigences d'allocation, les questions législatives entourant la relativement nouvelle Water Act ef la roile de fond juridique générale des liniges sur les eaux. Puis. on cible aussi les récents exemples où le droit légal a surgi, sans toutefois avoir été réglé de manière definitive.

\section{TABLE OF CONTENTS}

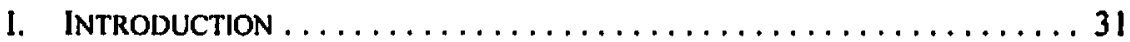

II. WATER REgULATION IN ALBERTA $\ldots \ldots \ldots \ldots \ldots \ldots \ldots \ldots \ldots \ldots$

A. Alberta Water LaW Prior to the Water ACt $\ldots \ldots \ldots \ldots, \ldots 33$

B. THE WATER ACT ........................... 35

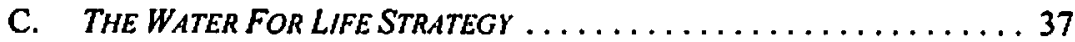

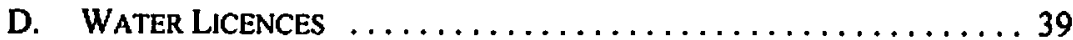

III. THE POTENTIAL FOR CONFLICT IN WATER ALLOCATION ......... 40

A. APPLICATIONS FOR LICENCES TO DIVERT WATER: MOUNTAIN

VIEW REGIONAL. WATER SERVICES COMMISSION V. DIRECTOR, CENTRAL REGION, REGIONAL SERVICES, ALBERTA ENVIRONMENT RE: CAPSTONE ENERGY ...................... 41

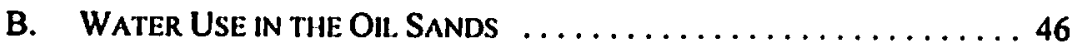

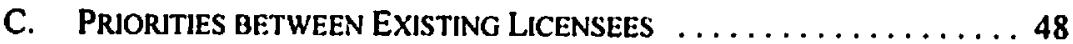

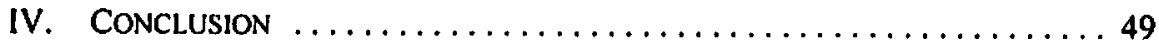

\section{INTRODUCTION}

Although Canada is known for its abundance of water, in some areas of Alberta water is in short supply. There are many competing demands for Alberta's water and demand is growing for this finite resource. Agriculture has played an important role in the development of Alberta and irrigation remains the largest use of water in the province. Municipalities need increasing amounts of water as Alberta's cities and towns continue to grow. Among other uses, the oil and gas industry requires water for drilling wells, enhanced recovery techniques and the exploitation of the oil sands.

Randall W. Block, Partner, at Borden Ladner Gervais LLP and Joel Forrest, Legal Counsel, Power and Regulatory Law at TransCanada PipeLines Limited. The writers gratefully acknowledge the assistance of Carol Hamm, also of Borden Ladner Gervais LLP Finally, the assistance and review of Professor David Percy, Q.C. has been invaluable. 
In 2004, after several years of below average rainfall, allocation of water in Alberta is once again a politically and emotionally charged topic' and the use of water by the oil and gas industry is increasingly under attack. ${ }^{2}$ Diversion and use of water is currently governed by the Water Act. $^{3}$ Although under the Water Act a framework for water management planning in Alberta was to be developed, ${ }^{4}$ there are currently no complete water management plans. In response in part to this deficiency, in November 2003 the Government of Alberta released the Water for Life Strategy that among other objectives outlined a process for development of approved water management plans for Alberta's major water basins.

The perceived shortage of fresh water, coupled with the release of the Water For Life Strategy, has once again focused attention on the complex and little understood area of water law. In times of shortage, users of water will necessarily focus on their legal rights to water and enforce their entitlements if necessary. ${ }^{6}$ To date, there has been a paucity of regulatory and court decisions defining entitlements to water. However, as competition grows, conflict is inevitable. Ultimately, entitlement will be determined by reference to the applicable water law. Unfortunately, given that water licences have been issued over many years, under different statutory regimes, with conditions that vary widely, the answers are not straightforward.

As we discuss below, the battleground for new allocations will be the requirements that must be satisfied before a licence is issued and, if issued, the conditions attached to the licence. However, the Water $A c t$ has only been law since 1999 and legislative change does not occur in a vacuum. Prior licences, many of which were granted without term and in practice treated as perpetual in nature, were grandfathered under the Water Act. Both the prior legislation and the Water Act enshrine the principle of first in time, first in right. Therefore, in addition to conflicts that may arise on the application for new licences, conflict may also arise due to vested rights under older licences that have priority over subsequent allocations of water. In this article, we discuss the legal backdrop to water conflict. We then focus on recent examples where legal entitlement to water was raised, but not definitely resolved.

"Taylor Takes Longer View," Editorial, Calgary Herald (3 May 2004) Al0; Alberta Environment, Advisory Committee on Water Use Practice and Policy - Preliminary Report by D.O. Trew, D. Pryce \& Dr. M. Griffith (Edmonton: Alberta Environment, 2004) [Advisory Commitfee].

See e.g. Mary Griffiths \& Dan Woynillowicz, Oil and Troubled Waters: Reducing the impact of the oil and gas indusiry on Alberta's water resources (Drayton Valley: Pembina Institute, 2003), online: The Pembina Institute <iwww.pembina.org/pdf/publications/OilandTroubledWaters.pdP; see also Canadian Association of Petroleum Producers (CAPP), Technical Report: Use of Water by Alberta's Upsiream Oil and Gas Indussiny" (Calgary: CAPP. 2002), online: CAPP <www.capp.ca/raw.asp? NOSTAT $=$ YES\&dt $=N T$ T \&EPDF\&dn $=56487>$.

Ibid., s. 7.

Alberta Environment, Water for Life: Alberta's strategy for sustainability (Edmonton: Alberta Environment, 2003), online: Water for Life <www.waterlorlife. gov.ab.ca> [Water For Life Strategy]. See e.g. Mountain Vielw Regional Water Services Commission v. Direclor. Central Region. Regional Services, Alberta Emironment re: Capstone Energy (26 April 2004), Appeal Nos. 03-1 16 and 03-1 18 121-R at para 4 (AEAB), online: <www3 gov.ab.ca/eab/dec/03-116_118-121-R.pdB [Capsione]. 


\section{WATER Regulation in Alberta}

\section{A. Alberta Water LaW Prior to the WAter aCt}

In order to address current potential conflicts in water allocation, a brief review of the history of water law in Alberta is necessary. Significant legislative change in the form of the Water $A c r$ came in 1999. Licences predating the Water $A c t$ are grandfathered under the Water $A c t$ and allow the diversion of water with minimal conditions. Over time, water licences have become more sophisticated, reserving increased regulatory discretion to curtail water use. Therefore, in any conflict over water allocation, there is the very real possibility of conflict between different rights, vested under different statutes at different times, with different conditions as to use.

Water regulation in Alberta began in the latter half of the nineteenth century. At that time, access to water was governed by the common law doctrine of riparian rights. The riparian rights doctrine held that only those landowners whose land was adjacent to a watercourse had rights to the water in that watercourse. Riparian rights were restricted to the use of water for domestic purposes, except in the circumstance where the use of water for non-domestic purposes would not perceptibly diminish the natural flow of the watercourse. ${ }^{8}$ The doctrine of riparian rights posed a serious problem for the agricultural development of the prairies, especially in the arid southern regions because landowners whose land was not adjacent to a watercourse did not have access to water in order to water their crops.

Reform came with the enactment of the North-West Irrigation Act." This federal Act declared that all property in and the right to the use of all water is vested in the Crown. ${ }^{10}$ This allowed the government to establish a system whereby licences were granted for the use of water. A licence permitted the holder to divert and use the designated amount of water on the land indicated in the licence. To access water, it was no longer necessary that a landowner own land adjoining a watercourse. The licences granted under the North-West Irrigation Act specified the amount of water to which the licence holder was entitled, but did not restrict the term of the licence. These licences have been treated as perpetual in nature."

The North-West Irrigation Act also established the concept of first in time, first in right, with respect to water allocation. This principle, borrowed from American law of prior

' For a thorough review of the development of water law in Alberta, see David R. Percy, "Seventy-five Years of Alberta Water Law Maturity, Demise \& Rebirth" (1996) 35 Alta. L. Rev. 221 at 223 [Percy]: for a discussion of the genesis of the Waler Act, see David R. Percy, "Water Rights in Alberta" (1977) I5 Alla. L. Rev. 142; for an analysis of the Water Acr. see David R. Percy, "Water Rights Under the Water Act, 1996: Licences. Approvals and Other Forms of Right" (Paper presented to the Legal Education Society of Alberta Water Act Seminar. Calgary, Alberta. 23 October 1998) at 6-7 (Percy II]. Embrey v. Owen (1851). I55 E.R. 579.

S.C. 1894, c. 30 [North-West Irrigation ACt].

Percy, supra note 7 at 223 where Professor Percy notes that in the original North-West /rrigation Act, S.C. 1894, c. 30, it was merely the right to the use of water that was vested in the Crown. In 1895, the section was retroactively amended to vest in the Crown both the property in and the use of the water. 
appropriation, ${ }^{12}$ dictated that in times of shortage those licensees who obtained their licences first in time were the last to be cut off from the water supply. Conversely, the last person to have received a licence was the first person to be cut off in times of scarcity.

Although the North-West Irrigation Act successfully encouraged the development of agriculture in Alberta, it was not without its shortcomings. For instance, in its original form, the North-West Irrigation Act did not provide for a hierarchy among the uses of water. Nor did it provide for the transfer of water from an existing licensee to a new user. Consequently, if the water supply ran short the only mechanism for determining who received water was the priority established through the licences. ${ }^{13}$ Concem grew that irrigation would use most of the available water, leaving growing municipalities without adequate water supply. ${ }^{14}$

In 1921 the Irrigation $\mathrm{ACl}^{15}$ was amended to establish preferential uses for water. The highest priority was domestic use, followed by municipal, then industrial and finally irrigation and other purposes. ${ }^{16} \mathrm{~A}$ person requiring water for a higher purpose could apply to have all or part of the licence of a person with a lower priority use cancelled in order to gain access to water. The owner of the cancelled or partially cancelled licence was entitled to be compensated by the applicant for damages resulting from the cancellation. ${ }^{17}$ The creation of a hierarchy of uses superficially addressed the problem of conflicting uses for water, but otherwise transfers of water allocations under licences were still prohibited and any change to the priorities for water use required legislative amendment. ${ }^{18}$

In 1930, water resources came under provincial jurisdiction through the Water Resources $A c t,{ }^{19}$ which provided for essentially the same water rights regime as the Irrigation Act.

One of the major flaws of both the Irrigation Act and the Water Resources Act was that neither $A c t$ provided incentives for water conservation. Most water licensees obtained their water rights for little or no fee. Furthermore, licensees were prohibited from transferring those rights to another party. ${ }^{20}$ So long as the use of water could reduce the cost of other inputs in manufacturing or agriculture, users would be inclined to use as much "free" water as they were allocated. Conserving water would not result in savings. In the result, the system in many respects encouraged water use. ${ }^{21}$ In addition, the system was relatively inflexible. Licences were often issued with minimal, if any, conditions limiting the ability of the

Prior appropriation in the United States used a priority system based on the date when a person first made beneficial use of the water.

Percy, supra note 7 at 225 where Professor Percy notes that there was no specific prohibition on the transfer of water right between users until the first provincial water act in 1931.

Percy, ibid.

The name of the North-West Irrigation Acr was changed to the Irrigation Acl, R.S.C. 1906, c. 61. Irrigation Act, S.C. 1920, c. 55, s. 4.

Irrigation ACt, R.S.C. 1927, c. 104, s. 10.6.

Although transfers were prohibited, it was still possible to acquire water rights by purchasing land to which a water licence was connected.

S.A. 1931 , c. 71.

Percy, supra note 7 at 226 where Professor Percy suggests that one of the reforms needed to improve water legislation was to legislate a more liberal water transfer regime. In this article we have not discussed the ability to gain access to water under the transfer provisions of the Water Act. However. the acquisition of rights to water by commercial transaction is one way of avoiding conflict.

Percy, ibid. 
regulators to respond to future events. Reform of water law was clearly necessary and came in the form of the Water $A c t,{ }^{22}$ which was enacted in 1996.

\section{B. THE WATER ACT}

The Water $A c t$ was proclaimed in force in 1999 and recognizes that the sustainability of water use must be analyzed on a river basin basis. Alberta's water resources are divided among seven major river basins. ${ }^{23}$ Each basin has unique characteristics, sources of water and water issues.

Fundamentally, the Water Act preserved the priority system of first in time, first in right. The Water Act also created four categories of water rights holders: household users, traditional agricultural users, existing licensees and new licensees. ${ }^{24}$ The $W$ ater $A c t$ authorizes household users to divert a maximum of 1,250 cubic metres per year of surface water or groundwater for household purposes without the requirement of a licence, ${ }^{2 s}$ and household users enjoy priority over all other categories of water rights. ${ }^{26}$ Traditional agricultural users are a new category of rights holder that are entitled to priority for up to 6,250 cubic metres per year under a registration. ${ }^{27}$ Priority among water licensees and traditional agricultural users is established through a priority number assigned to their licence or registration. ${ }^{28}$ The Water Act provides that a licensee or registration holder with a "numerically lower priority number is entitled to divert the whole allocation of water specified under the licence or registration before a licensee or traditional agricultural user has any right to divert water pursuant to a licence or registration that has a numerically higher priority number." 29

The third category, existing licensees, have rights to water that have been granted over the last century under prior legislation. Existing licensees are considered deemed licensees under the Water $A c t$. Deemed licensees retain their original priority numbers and are permitted to exercise their right to divert water subject to the terms and conditions of the licence, even if those conditions are inconsistent with the Water $\mathrm{Act} .{ }^{30}$ Hence, the holder of a grandfathered

:2 Water Act, supra note 3.

"The major river basins in Alberta are: the Peace/Slave River Basin, the Alhabasca River Basin, the North Saskatchewan River Basin, the South Saskatchewan River Basin. the Milk River Basin, the Beaver River Basin and the Hay River Basin. Supra note 3, Part 3.

lbid., s. 21.

36 Ibid. S. 27. The significance of this is that household users would not be permitled to transfer unused portions of their allocation of 1,250 cubic metres per year.

" lbid., ss. 73, 28. A person who is a riparian or ground water user may apply for a registration for use of up to 6.250 cubic metres of water per year for the purposes of raising animals or applying pesticides to crops as part of a farm unit. The priority number of a registration corresponds to the date of the lirst known diversion of water: Water Act, ibid. s. 28. There is also the concept of an exempt agricultural user, who is permilted to divert up to 6.250 cubic metres per year without the requirement of a licence. but does not enjoy any priority under the Water $A C t$.

:" lbid., s. 30(2).

w Ibid., s. 18(I). Every authority or licence oller than a temporary authority, agreement, permit, interim licence, updated and reissued interim licence and supplementary interim licence, granted under a predecessor Act that on I January 1999 authorizes the diversion of water, is a deemed licence that has a priority number that corresponds to the priority number of the original authority or licence. 
licence can likely insist that its entitlement to water is "vested" by the terms of the licence and cannot be altered by the Minister acting under the Water Act."

The final category of water rights holders under the Water Act are new licensees. New licensees must not only comply with the provisions of the Water Act and the terms and conditions of the licence, they must also observe the grandfathered rights of deemed licensees. ${ }^{32}$

In order to issue a water licence under the Water $A c t$, there are a number of criteria that the Director" "must" or "may" take into consideration:

SI(4) In making a decision under this section, the Director

(a) must consider, with respect to the applicable area of the Province, the matters and factors that musl be considered in issuing a licence, as specified in an applicable approved water management plan,

(b) may consider any existing, potential or cumulative

(i) effects on the aquatic environment.

(ii) hydraulic, hydrological and hydrogeological effects, and

(iii) effects on household users, other licensees and traditional agriculture users, that result or may result from the diversion of water, operation of a works or provision or maintenance of a rate of flow of water or water level requirements, and

(c) may consider

(i) effects on public safety,

(ii) with respect to irrigation, the suitability of the land for irrigated agriculture, and

(iii) any other matters applicable to the licence that in the opinion of the Director are relevant, including any applicable water guideline, water conservation objective and water management plan.

The Water Act obligates the Director to consider the factors identified in an approved water management plan. However, to date only one of Alberta's major river basins, ${ }^{34}$ the South Saskatchewan River Basin, has a partial approved water management plan. ${ }^{35}$ Because the factors identified in approved water management plans must be considered by the Director, water management plans (if and when they are developed) will significantly impact the issuance of water licences.

" Percy II, supra note 7 at 6-7 where Professor Percy points out "many modern licences on the South Saskatchewan River are subject to a requirement that the diversion of water shall not be permitted unless a minimum residual flow of 1500 cubic feet per second is maintained in the river. If the Minister were to set a higher minimum instream flow pursuant to the provisions of the Water $A C t$, the holder of a deemed licence would be entitled to observe the lower minimum flow requirement specified in its licence."

1. Supra nute 3, s. 18.

" Ibid., s. 163(1) where it states: "The Minister may, by order, designate employees of the Government under the administration of the Minister as Directors for the purposes of all or a part of this Act."

" Supra note 23.

is Although Phase l of the South Saskatchewan River Basin water management plan has been approved, it only addresses water allocation transfers. The development of Phase II, which will address surface water conservation, is currently under development. 
Whereas licences under the Water Resources Act were often issued with no or minimal conditions, licences under the Water $A c t$ often contain expansive conditions. As will be discussed below, Alberta Environment apparently views these conditions as providing the unfettered discretion to curtail water allocations.

\section{THE WATER FOR LIFE STRATEGY}

Enshrined in the Water Act is the requirement that the Minister establish a framework for water management planning and a strategy for the protection of the aquatic environment of Alberta. ${ }^{36}$ In partial response to this requirement, the Government of Alberta released, in November 2003, the Water For Life Strategy. The purpose of the Water For Life Strategy is to provide a plan of action to achieve the following goals:

- Safe, secure drinking water,

- Healthy aquatic systems, and

- Reliable, quality water supplies for a sustainable economy. ${ }^{37}$

The Water for Life Strategy outlines action plans for knowledge and research, partnerships, and water conservation. Water management plans, which are to be developed for all of Alberta's major river basins, are important tools that provide a legal mechanism to help achieve the goals of the Water For Life Strategy. ${ }^{38}$ Water management plans should form the interface between the policy objectives in the Water for Life Strategy and the Water Act.

Water management plans are intended to recognize that regulating the diversion and use of water in seven major river basins, each with unique circumstances, with a single $A c t$ would be virtually impossible. Approved water management plans adapt the provisions of the Water $A c t$ to the circumstances of individual river basins. Approved water management plans will also allow for local input that reflects the characteristics and concerns of an individual watershed, rather than having a single $A c t$ administer water resources as if water resources and uses were uniformly distributed across the province. The Water for Life Strategy also calls for three levels of partnerships to be established. At the provincial level there will be a Provincial Water Advisory Council. At the watershed level, the Water for Life Strategy calls for Watershed Planning and Advisory Councils. At the local level, Watershed Stewardship Groups will be established. The Watershed Planning and Advisory Councils will take the lead on developing water management plans. ${ }^{39}$

As noted above, to date only the South Saskatchewan River Basin has an approved water management plan, and this plan only addresses water allocation transfers as contemplated in the Water Act. Phase II of the South Saskatchewan River Basin water management plan is currently being developed and will address water conservation objectives. The remaining water basins in Alberta have yet to develop approved water management plans. 
To become an approved water management plan under the $W$ ater $A c t$, a water management plan must be approved by either the Lieutenant Governor in Council or the Minister of the Environment, and:

(a) must include

(i) a summary of the issues considered in the water management plan,

(ii) a description of the area of the Province to which all or part of the water management plan applies,

(iii) a summary of the recommendations of the Minister, and

(iv) the matters or factors that must be considered deciding whether

(A) to issue an approval, preliminary certificate or licence or effect a registration, or

(B) to approve a transfer of an allocation of water under a licence,

in the area of the Province to which the approved water management plan applies, and

(b) may include

(i) the number of households permitted on a parcel of land for the purposes of section 21,

(ii) authorization of the ability to transfer an allocation of water under a licence,

(iii) authorization of the ability to withhold water under section 83, and

(iv) a provision on the maximum amount of water that may be diverted under a registration. ${ }^{40}$

An approved water management plan will define the factors that must be considered when issuing licences, preliminary certificates and approvals. As well, the water management plans envisioned in the Water for Life Strategy would provide the Director with the authority to approve the transfer of water allocations in all of Alberta's major river basins. ${ }^{41}$

For example, Phase I of the South Saskatchewan River Basin water management plan authorizes the Director to consider applications for water allocation transfers and use water conservation holdbacks. ${ }^{42}$ The South Saskatchewan River Basin water management plan establishes a number of factors that must be considered in reviewing an application for a transfer of an allocation of water under a licence in the South Saskatchewan River Basin. The South Saskatchewan River Basin water management plan establishes that one of the factors to be considered is the "[e]xisting, potential and cumulative effects on the aquatic environment and any applicable instream objective and/or water conservation objective." Among the criteria for approval is that there be no significant adverse effect on the aquatic environment, existing instream flow objectives or conservation objectives resulting from the transfer. ${ }^{44}$ Other factors identified in the South Saskatchewan River Basin water management plan that must be considered are: linkages between ground water and surface water as a result of the transfer; potential and cumulative hydraulic, hydrological and hydrogeological effects of the transfer; and existing, potential and cumulative effects on household users, traditional

1: Supra note 3, s. 83. This section authorizes the Director to withhold up to 10 percent of an allocation of water under a licence that is being transferred, if the Director is of the opinion that it is in the public interest to prolect the aquatic environment or implement a water conservation objective. 
agriculture users and other higher and lower priority licensees. The plan also stipulates the criteria required to be met in order to grant a licence. ${ }^{45}$

Water management plans may also affect the term for which licences are granted. The Water (Ministerial) Regulation ${ }^{46}$ states that the Director must consider a number of factors when determining the term of a licence. The factors include any applicable water management plan, the purpose of the licence, the area of the province in which the diversion of water is located and the expected duration of the project.

Due to the mandatory requirement for the Director to consider the factors identified in an approved water management plan, these plans will directly affect the ability of water users to obtain water licences and the likely terms and conditions attached to the licences. It will be important for water users, including the oil and gas industry, to be involved in the planning process at all levels to ensure that their interests are reflected in approved water management plans.

\section{WATER LiCENCES}

Older water licences typically did not have onerous terms and conditions. Under the Water $A c t$, these older licences have been grandfathered as deemed licences. To the extent that the deemed licences contain terms and conditions that conflict with the Water Act, the terms and conditions of the deemed licences prevail. ${ }^{47}$ Whereas older licences often contain few conditions, water licences granted under the Water $A c t$ increasingly contain extensive conditions with the apparent goal of reserving to the Minister the discretion to alter water allocation in response to future circumstances.

For example, the terms and conditions in some of the older licences contain standard provisions that indicate that a licensee's right to water could be limited in order to "ensure an equitable apportionment of the waters in compliance with the Water Resources $A c t$, and the regulations made thereunder from time to time." as:

The rights and privileges liereby granted are subject to periodic review and to modification to ensure the most beneficial use of the water in the public interest and more particularly to ensure preservation of the rights of other water users. ${ }^{40}$

Although the licences indicate that water allocations could be modified for the equitable distribution of water, the apportionment of water must be in compliance with the Water Resources Act. Instead of allowing for rateable reductions in water allocations across licensees (regardless of priority), the Water Resources $A c t$ states:

\section{is Ibid. at 9.}

4. Alta. Reg. 205/98, s. 12.

St Supra note 3, s. $18(2)(b)$.

¿* Licence No. 1522, Red Deer River Drainage Basin, issued 25 March 1976 to Chevron Standards Limited [Licence No. 1522].

1" Licence No. 08744, Red Deer River Drainage Basin, issued 30 April 1984 to the City of Red Deer [Licence No. 08744]. 
35 (1) Licensees have priority among themselves according to the number of their licences, so that each licensee is entitled to receive the whole of the supply to which his licence entitles him before any licensee whose licence is of a higher number has any claim to a supply. ${ }^{\text {so }}$

Although the Water Act expressly maintains the first in time, first in right principle," the conditions attached to licences have become increasingly sophisticated. For example, licences have progressed from having few conditions ${ }^{32}$ to licences with conditions that expressly indicate restrictions on the allocation of water ${ }^{33}$ and most recently to licences that specifically provide that the Director reserves the right to establish instream flow needs for the water resource. ${ }^{54}$

The apparent goal of the conditions in water licences is to empower the Director with increased discretion. However, the licence provisions that purport to allow the Director increased discretion to amend allocations do not override the first in time, first in right principle. For instance, even if the determination of instream flow objectives has the effect of reducing the amount of water available, as between licensees the priorities are unchanged. Conditions set forth in licences must still comply with the Water Act." A licensee is entitled to the whole of their allocation of water prior to a licensee of lower priority. The appropriate course of action, as required by the first in time, first in right principle, is to cut off licensees of lower priority in order to achieve instream flow objectives. ${ }^{56}$

\section{The Potential for Conflict in Water Allocation}

Thus, the obstacles to obtaining a water licence appear formidable. The requirements of the Water $\mathrm{ACl}$ must be satisfied. If and when approved management plans come into existence, their requirements must be considered. Where there are prior users, there are likely vested rights that require full allocation of water prior to a new licensee obtaining access to water. ${ }^{37}$ Finally, even once a licence is issued, there may well be disputes over the ability of the Director to amend the licences, relying on the conditions, in contravention of the first in time, first in right principle. In short, competition for water will undoubtedly create conflicts; however, there is a lack of certainty as to how the conflicts will be resolved. We now turn to some examples where conflict over access to water has arisen.

"Water Resources AcI, R.S.A. 1980, c. W-5, s. 35(1).

"Supra note 3, 5. 30(2).

$32 \quad$ Licence 1522, supra note 48.

si Licence 08744 , supra note 49.

s4 Licence 00188992-00-00. Athabasca River, granted to True North Energy L.P.. I I September 2002.

ss Subordinate legislation or decisions made pursuant to an cnabling act, in order to be valid. must fall within the terms of the enabling statule. See Heppner v. Alberta (Minister of Environment) (1977). 4 Alta. L.R. (2d) 139 (S.C.(A.D.)).

3. Supra note 3, S. 30(2).

57 Ibid, ss. 81-82. It is also possible for new users to obtain a water licence through a transfer from a licensee. 


\section{A. APPLICATIONS FOR LICENCES TO DIVERT WATER: MOUNTAIN VIEW REGIONAL WATER SERVICES COMMISSION V. DIRECTOR, CENTRAL REGION, REGIONAL SERVICES, ALBERTA ENVIRONMENT RE: CAPSTONE ENERGY ${ }^{38}$}

Concerns about water use for underground injection arose during the public consultation of the Water for Life Strategy held in 2002. As a result, a multi-stakeholder committee, the Advisory Committee on Water Use Policy and Practice, was established to examine whether changes are needed to improve management of water related to underground injection. On 31 March 2004, the Advisory Committee released its preliminary report and indicated that its final report would be issued by 30 June $2004 .{ }^{30}$ The Advisory Committee concluded that opportunities for further reduction in the use of non-saline water for underground injection must be pursued and set forth eight recommendations. Notably, the Advisory Committee identified the potential to include surface water sources but did not reach consensus. Stakeholder input on expanding the Groundwater Allocation Policy to include both ground and surface water throughout the province was to occur during April and May 2004. Presumably, the work of the Advisory Committee will result in a revised policy governing the use of fresh water for enhanced oil recovery.

No doubt, the use of fresh water for enhanced oil recovery is a politically and emotionally charged issue. The Advisory Committee appears to have agreed with the opponents to the use of fresh water for injection purposes that the water is effectively lost to the hydrologic cycle. The Advisory Committee also noted that over 50 percent of conventional light oil each year is now supplied by enhanced oil recovery projects and that, in 2001, \$447 million in direct royalties were generated from conventional and thermal enhanced oil recovery activities. As aptly stated by the Environmental Appeals Board (EAB), "[i]t has been said that, at least in Alberta, a loaf of bread is actually made of oil (along with the hard work of those in the agriculture industry). Most Albertans are dependent on the oil industry in some way to pay their bills and buy their food."60

On 19 May 2004, the EAB released its decision on the appeal of Capstone Energy Ltd.'s preliminary certificate to divert water from the Red Deer River and in so doing charged headlong into the policy debate over the use of fresh water for enhanced oil recovery. As held by the EAB, "when fresh water, regardless of its source, is injected into the ground for the purposes of oilfield injection, it is for all practical purposes lost - it is lost to us, it is lost to our children, and in this case, our children's children for thousands of generations to come." ${ }^{61}$ Understandably, the Capstone case had become a lightning rod for water issues such as the appropriate uses for fresh water and the competition for water between the oil and gas industry and municipalities and agriculture.

By way of background, Capstone applied for a licence to divert 328,000 cubic metres of water per year from the Red Deer River to use for oilfield injection (industrial) purposes in 
the Red Deer River sub-basin of the South Saskatchewan River Basin. The water was to be obtained from surface water obtained using shallow wells $(20 \mathrm{~m})$ constructed in the alluvial gravels located adjacent to the Red Deer River. ${ }^{62}$ Capstone's initial assessment of source water established that a diversion of $1000 \mathrm{~m}^{3} /$ day represented "less than $1 \%$ of the average minimum measured flow of the Red Deer River at the site."

On 7 July 2003, a designated Director under the Water Act issued a Preliminary Certificate to Capstone. Following the issuance of the Preliminary Certificate, a number of landowners and municipalities appealed the decision to issue the water licence. ${ }^{64}$

The grounds of appeal included that it was inappropriate to use surface water for oil field injection purposes, that there was insufficient consideration of alternatives to the use of surface water and that there would be insufficient water for the future plans of the City of Red Deer to supply water to Hobbema, Blackfalds and Lacombe. ${ }^{\text {s5 }}$ Local landowners cited low river levels and concern that any adverse effects on the water supply would affect their ability to raise cattle. ${ }^{60}$

The Environmental Appeals Board agreed to address a long list of issues ranging from whether the purpose for which water will be used is a valid reason to refuse an application for an allocation of water under the Water Act to whether adequate testing was done to be able to predict the long-term impacts of the project on the immediate neighbours. ${ }^{67}$

Capstone Energy Lid./Water Act Preliminary Certificate 00198509-00-00. EAB File No.: EAB-03-1 16, 118,199,120,121, Affidavil of Brad Graham, Capstone Energy Lid. at 2-3. Capstone Energy Lid./Water Act Preliminary Certificate 00198509-00-00, EAB File No.: EAB-03-116. 118,199,120,121, Assessment of Sourcewater Options for the Tindestoll Belly River Oil Pool Flood Program T36 RI W5M, Waterline Resources Inc., December 2002 at 4-5. The Mountain View Regional Water Services Commission draws water from the Red Deer River and provides water to the Municipalities of Innisfail, Bowden, Olds, Didsbury, Carstairs and Crossfield. Capstone Energy Ltd./Water Act Preliminary Certificate 00 198509-00-00. EAB File No.: EAB-03-116, $118,199,120,121$. Notice of Appeal of the City of Red Deer at 3. Capstone Energy Ltd./Water Act Preliminary Certificate 00198509-00-00. EAB File No.: EAB-03-1 16, $118,199,120,121$, Notice of Appeal of Gerald Oxtoby, Section IV.

(11 February 2004), Appeal Nos. 03-116 and 03-118-123-IDI at paras. 162-233 (AEAB). The entire list of issues to be considered at the hearing of the appeals is as follows:

1. Purpose

a. What role does purpose for which the water will be used have with respect to the allocation of water under the Water Acr?

b. Is the use of water for oilfield injection a valid reason to refuse to grant an allocation of water under the Water ACr?

c. Has the Director adequately balanced the economic benefits and environmental impacts of this project?

d. Has the Director adequately considered alternatives to the use of water for this project, including the economics of those alternatives?

e. Has the Director adequately considered the removal of the allocated water from the hydrological cycle?

2. Protection

a. Does the Preliminary Certificate and Proposed Licence provide adequale protection for: (1) other water users, (2) recreational users, (3) fish and wildlife, and (4) the aquatic environment, including instream flow needs?

b. Are the Terms and Conditions of the Preliminary Certificate and Proposed Licence adequate with respect to: (1) monitoring, (2) reporting. (3) minimum flow rates, and (4) maximum pumping rates. 
After an exhaustive discussion of a case that the EAB described as "one of the most difficult 'balancing act' cases to come before the EAB in its ten plus years of existence," the EAB upheld Capstone's Preliminary Certificate but reduced its allocation of water to $600 \mathrm{~m}^{3}$ per day for a total of $219,000 \mathrm{~m}^{3}$ annually. The EAB candidly admitted that "[w]e are effectively being asked to choose between competing purposes for water use."68

The Capstone decision is critical for at least the following reasons:

- The EAB held that, under s. 2 of the Water Act, the Director, in issuing a licence, must consider the purpose for water use;

The same rigour must be applied to surface and ground water withdrawal;

An applicant must satisfy a two-step process to obtain a water licence for the use of fresh water; and

There are significantly increased evidentiary requirements on an application for a water licence that have the potential to turn these applications into significant regulatory applications.

The EAB held that the Director must consider the purpose for the use of the water. Central to the EAB's analysis was the finding that oilfield injection removes fresh water from the hydrologic cycle forever. However, there is no express provision in the Water Act that compels the Director to consider the purposes for which water will be used. The Director, arguing against the appeal, indicated that the purpose for which water was to be used was not a factor to be considered and would require legislative amendment. In addition, the Minister under s. 34 of the Water $A c t$ could disallow a use, but clearly had not done so for enhanced oil recovery. The criteria identified by the Water Act in s. 51(4) do not make reference to the use of the water as a relevant consideration to obtain a licence. ${ }^{69}$ The Director submitted that

c. Is the term of the Proposed Licence appropriate?

d. Are the renewal mechanisms relating to the Proposed Licence appropriate?

3. Volume

a. Is the volume of water allocated appropriate, including taking into account the proposed length of the project and the availability of water in the Red Deer River?

b. Has the Director adequately considered the impact of this allocation on future water users, including the future needs of municipalities?

c. Should the volumes of water be allocated in some staged manner?

4. Immediate Neighbours

a. Has the Director adequately considered the potential impacts of the project on the immediate neighbours to the project, being Mr. Oxtoby, Mr. Little, and Mr. Smith?

b. Was the testing undertaken sufficient and adequate to predict the long-term impacts of the project on the immediate neighbours?

c. Do the immediate neighbours to the project have adequate protection in the event there is an impact on them?

5. Policy Considerations

a. Has the Director properly taken into account all the applicable policies of the Government of Alberta?

b. Do the Preliminary Certificate and Proposed Licence adequately allow for any changes regarding the policy direction on oilfield injection?

c. Has the Director adequately taken into account the sustainability of the Red Deer River Basin and the South Saskatchewan River Basin?

6 Capsione, supra note 6 at para 4.

69 The provision does identify the suitability of land for irrigation as a criteria for obtaining licence, but that is an evaluation of the land and not the use of that water. 
the municipalities were seeking to have municipal use rank above industrial use; however, he did not have the authority to rank the purposes of an allocation in consideration of a licence application. Priority by use would require legislative amendment. Thus, the Director submitted that Capstone had satisfied all requirements and therefore a water licence could not be refused.

The EAB disagreed and relied on the general powers and purposes of the Water $A c t$ set forth in $\mathrm{s.} 2$ of the $A c t$ to find that the Director is required to consider the purpose of water use in order to properly apply the $\mathrm{Water} A \mathrm{At}^{70} \mathrm{~A}$ determination of the factors that are relevant to a specific application would not be possible without considering the purpose for which the water is to be used.

Once purpose is considered, the critical factual inquiry is that injected fresh water is effectively lost. In the words of the EAB:

\begin{abstract}
Accordingly, the fact that oilfield injection does not return water to the river basin is critically relevant to determining the effects on the aquatic environment and on other users. It is that issue, the shared responsibility of water management, and the ownership of water by all Albertans that underscores the approach taken by the Board with respect to these appeals. ${ }^{71}$
\end{abstract}

Therefore, the EAB specifically found that "[s]ection 2 of the Water Act requires, in our opinion, that any use of water resulting in the loss of fresh water from the hydrologic cycle requires much greater scrutiny."

On finding that the purpose of the use of water must be considered and that injected fresh water is effectively lost forever, several critical findings inexorably followed. First, although there seemed to have been significant debate on whether Capstone was seeking to withdraw ground water or surface water, in the end it mattered naught. The EAB specifically held that it was

of the view that [the Ground water Evaluation] Guideline does not override the Water Acs or that a less rigorous approach for the allocation of surface water for oilfield injection is appropriate. Fresh water, whether from a ground water source or surface waler source, is a scarce natural resource, having greal value to all Albertans. and there is no reasonable basis on which to justify a more stringent approach to tlie use of one source of fresh water over another in times of increasing demand for both surface and ground water, which we find to be the case particularly in the Red Deer region."

Although the Advisory Committee did not reach consensus on the issue and is undertaking a process of public consultation on the point, the EAB effectively wiped out any distinction between surface and ground water withdrawals, relying again on $\mathrm{s} .2$ of the Water Act. This leaves the very distinct possibility that if the Advisory Committee does in fact recommend 
a distinction, unless there is legislative change, the EAB would consider the policy contrary to the Water Act.

Building once again on the purposes of the Water $A c t$ and the finding that injected water is lost forever, the EAB fashioned a two-step process. First, only if there is no other feasible alternative (such as adjacent produced water) should fresh water be considered. Second, the applicant must establish that the required fresh water will be used efficiently. A "full" analysis would include the volume of water used and the results expected from the use of the water. Apparently, the applicant must assess the economic results obtained (enhanced oil recovered) against the fresh water used.

Finally, again building on its critical finding that the purpose of a water allocation must be assessed, the EAB placed a heavy burden on an applicant to provide extensive evidence of the economics and beneficial use of fresh water for injection purposes. The EAB recommended that the applicant be required to provide information concerning such things as the extra cost per barrel to use brackish water and the expected value of the recovered oil. The EAB also recommended that extensive information with respect to access to, and the economics of, sourcing and use of brackish or saline water.$^{74}$ Thus, the use of fresh water for enhanced oil recovery is, in the EAB's view, a last resort even though the evidence of Alberta Environment's expert was that the diversion of water would not have a "discernable impact on the river, the hydrologic cycle, the immediate neighbours or existing downstream users." 75

The EAB in Capstone also attempted to develop a graduated licensing scheme. Capstone was allowed $219,000 \mathrm{~m}^{3}$ per year. If Capstone requires more water once it reaches full production, the EAB indicated that Capstone should find alternate sources for that water. If Capstone is unable to obtain alternate water, the EAB invited Capstone to apply again for the additional water needed. ${ }^{76}$ This two-step process envisioned by the EAB will be a significant

Jbid. at para. 193. In the EAB's view the following information should be required by the Director to determine whether use of fresh water for oilfield injection is beneficial and consistent with the Water Act. This information includes:

(a) the extra cost per barrel of recovered oil if the applicant is required to use brackish water in the region;

(b) expected amount of oil to be recovered and its value;

(c) the expected cost of fresh water versus the other use of other water resources;

(d) an inventory of all wells, including fresh water wells, salt water wells, disposal wells and other wells within $3 \mathrm{~km}$ of the diversion point:

(c) an inventory of all other operators within the general area, in approximately a $20 \mathrm{~km}$ radius that may provide an alternative source of water. including salt water, brackish water. or produced water:

(f) any applicable information on recycling or reusing water;

(g) any geological data to provide an indication of the potential availability of brackish waler;

(h) an economic and technical review including: the total cost of the projecl and the value of enhanced oil recovery that might be gained, more details on the comparisons on the availability of brackish water, produced water, and fresh waler;

(i) a detailed explanation as to why brackish water or produced water can not be used;

(j) a review of other available technologies and their feasibitity, such as carbon dioxide or nitrogen;

(k) any other information the Director may require. 
impediment to obtaining the rights to adequate water. No doubt the second application would be subject to the same evidentiary requirements as outlined above with the added difficulty of justifying additional water resources. The two-stage approach to water licences, though it may have good intentions to conserve water, creates added uncertainty for industrial water users that rely on access to adequate water supplies for their operations.

The EAB held that its role in addressing the appeals in Capstone was to "balance the protection of our fresh water supplies with sustaining this essential element of our economy." Although this is a laudable goal, the EAB went beyond an assessment of whether the requirements of the Water $A c t$ were met for the issuance of the preliminary certificate to Capstone. In so doing, the EAB charged into the policy debate that is central to the work of the multi-stakeholder Advisory Committee. The Director candidly admitted that Capstone met all requirements for a water licence and that Capstone demonstrated that its diversion of water would not discernibly affect the volume of water in the river nor would its allocation affect the availability of water for other users. There was evidence before the $\mathrm{EAB}$ that the hydrologic cycle in the river basin would not be affected. In our view, questions as to whether Alberta's water resources should be used for oilfield injection at all are more appropriately dealt with through the political arena or in the development of approved water management plans. ${ }^{78}$

The Advisory Committee was to issue its final report by 30 June 2004 for consideration by the Minister. Whether the Advisory Committee's recommendations will accord with the reasons of the EAB in Capstone is yet to be seen. What is certain is that the Capstone decision, coupled with increased public scrutiny, will significantly increase the regulatory requirements of obtaining a water licence where water is used for enhanced oil recovery.

\section{B. WATER USE IN THE OIL SANDS}

In the Peace/Athabasca River Basin, water is primarily used by pulp and paper mills, by municipalities and for the intensive oil sands development underway in the Fort McMurray area. Both open pit mining and in situ bitumen projects using Steam Assisted Gravity Drainage (SAGD) place demands on water resources. Surface mining operations require the handling of large volumes of water and engage water issues with respect to:

disposal of produced water;

the source of the water used in the extraction process (groundwater or surface water); and

the quantity of water diverted for depressurization of the mine site and the effect that the depressurization has on the hydrogeology and surface water hydrology of the area.

" There are various stakeholder committees examining water use and environmental effects of water use including: The Advisory Committee on Water Use Practice and Policy. The Cumulative Effects Management Association and the Regional Aquatics Monitoring Program. 
SAGD operations consume water to generate steam that is then injected into the bitumen reservoir through a horizontal injector well, mobilizing the bitumen and allowing it to flow to a horizontal producer well and then to the surface. Much of the water used to generate steam is recycled, but some remains in the formation and cannot be recovered. As water is lost, make up water is required to continue the SAGD process. ${ }^{79}$

The oil sands development continues at a robust pace with recent Alberta Energy and Utilities Board approvals of the Shell Jackpine Mine and the Canadian Natural Resources Limited Horizon Mine. Licences under the Water Act that divert water directly from the Athabasca River ${ }^{80}$ have been allocated approximately $242,570,810 \mathrm{~m}^{3}$ per year. The oil sands projects account for approximately $223,993,350 \mathrm{~m}^{3}$ of the allocated water." In addition to the surface water allocations, there are millions of cubic metres allocated from groundwater sources.

Currently the Athabasca River Basin does not have an approved water management plan; however, work is being done by various groups, including the Cumulative Effects Management Association and the Regional Aquatics Monitoring Program to establish baseline environmental data that will be used to establish instream flow needs for the Lower Athabasca River, as well as managing watershed integrity and water quality for the Lower Athabasca River Basin. It will be important for oil sands developers to participate in the work of these groups and to become involved in the development of water management plans, as the water management plans will have a direct effect on the requirements to obtain licences. ${ }^{82}$

The environmental impact assessments from the most recently approved projects (Canadian Natural Resources Limited's Horizon Project and Shell Canada Limited's Jackpine Project) suggest that the groundwater diversions associated with the projects are expected to have effects on aquifer and surface water levels. ${ }^{33}$

Typically, SAGD operations access ground water for steam generation. ${ }^{84}$ In much the same way as Capstone was required to reduce freshwater consumption, SAGD developers will also come under increasing pressure to minimize fresh water use, access brackish or saline ground

74 Application to the Alberta Energy and Utilities Board by Husky Oil Operations Limited for approval of the Tucker Thermal Project, Application vol. 2 at 2.1.

Within the Regional Municipality of Wood Buffalo.

Based on water licence information provided by Alberta Environment.

Interjurisdictional issues with respect to the Mackenzie River may also have an effect on the availability of water licences and the conditions attached to them.

1 Application to the Alberta Energy and Utilities Board by Shell Canada Limited for approval of the Jackpine Mine-Phase I. vol. 3, s. 4 at 4-2-4-4; Application to the Alberta Energy and Utilities Board by Canadian Natural Resources Limiled for approval of the Horizon Project, vol. 2, s. 1 at 1-23; vo. 5, s. 3 at 3-63; vol. 5, s. 4 at 4-14.

* The following are examples of SAGD projects that obtain groundwater for steam production: ConocoPhillips Surmont In Situ Project (Grand Rapids); Nexen Opti Long Lake (Grand Rapids); PetroCanada Meadow Creek (Grand Rapids); Petro-Canada McKay River (Birch Channel); and EnCana Foster Creck (Ethyl Lake Formation). 
water sources for make up water requirements and increase water recycle rates with a

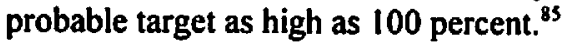

To date, water conflict in the oil sands has simmered but has not erupted. ${ }^{86}$ In relation to SAGD projects, the issues around access to water will likely continue to be centred on minimizing fresh water use, maximizing recycle rates and exploring (and ultimately likely using) saline or brackish ground water sources for make up water requirements. These requirements are encompassed in s. 51(4) of the Water Act and specifically mandated in s. 36 of the Oil Sands Conservation Regulation. ${ }^{87}$ In addition, the cumulative effects of the several announced and approved projects will be considered by the Director under 5.51 of the Water Act. At this stage, conflicts arising from competition for a scarce resource have not arisen.

Oil sands mines use large quantities of surface water in the extraction process, but to date the Athabasca River has not been extensively allocated. ${ }^{88}$ Unlike in the southern portions of the province, in the Athabasca River Basin, agriculture is not an extensive user of water. Actual conflicts arising from competition for a scarce resource have not, to the writers' knowledge, arisen. However, as discussed below, there was a harbinger of possible conflict to come in the recent Horizon Project application.

\section{Priorities between Existing Licensees}

The principle of first in time, first in right was a fundamental principle of the Water Resources Act that was carried through into the Water Act. As was discussed above, increasingly expansive conditions have been attached to water licences when issued. The conditions come in many forms and appear designed to permit the Director to curtail water allocations in response to changing circumstances.

In the Horizon Project application, Syncrude intervened for the limited purpose of asserting its rights to water under the first in time, first in right principle. In its decision, the Energy and Utilities Board noted that

Syncrude informed the Panel that water licences issued under the Water Act were subject to the principle of "first in time; first in right," which ensured that the allocations of earlier licensees were not impacted by future allocations. Syncrude stated that it had a statutory priority that could be overridden only in an emergency declared by the Lieutenant Governor in Council. Therefore, it was Syncrude's position that any water licence that might be issued to CNRL [Canadian National Resources Limited] could not impact Syncrude's existing

Water Recycle Guidelines and Water Use Information Reporting for In Situ Oil Sands Facilities in Aiberta (11 May 1989). Informational Letter IL. 89-5 (AEUB). See also Oll Sands Conservation Regulations, Alta. Rcg. 76/88, s. 36 where it specifically provides for in situ recovery schemes, that a project: 1) minimize the use of fresh make-up water: 2) minimize the disposal of water: and 3) maximize the recycle of produced water.

s. "Water controversy may douse Alberth oil sands boom" (3 July 2002), online: Planct Ark, <www.planet ark.com/dailynewsstory.cfm/newsid/16683/story.htm>.

"7 Sispra note 85.

* Alberta Environment, "Water allocation compared to availability" (22 April 2004), online: Alberta Environment, <www.gov.ab.ca/env/water/GWSW/quantity/waterinalberta/llocation/al2_availability cfm>. 
licence. Syncrude stated that it was its understanding that the only method by which CNRL could access existing licensed rights was by negotiating a voluntary transfer, as provided in the Water $\wedge$ ct. $^{89}$

Alberta Environment, in response, asserted:

AENV [Alberta Environment] stated that it believed that there were suflicient annual volumes of water in the Athabasca River to satisfy CNRL's allocation request and that of other potential users, because the withdrawals were a relatively low percentage of annual flow. However, it noted that liming of withdrawals during low flow mighı require careful management, as there was a potential for negalive cumulative effects during low winter lows. 90

Following these assertions from Syncrude and Alberta Environment, the Energy and Utilities Board indicated the following:

The Panel notes Synerude's argument that it has priority water rights under the Water Act for those licences it currently holds and that under the "first in time; first in right" principle, water licences issued after it was granted its licences cannot affect its earlier licences. The Panel notes that OSEC [Oil Sands Linvironmental Coalition] believed that this principle was contrary to the equilable use of water, but underslands that AENV [Alberna Environment] will recognize priority rights of all water users under the Water Act. It also notes that AENV has the ability to revise all waler licences regardless of priority, should it become necessary to meet the requirements of the IFN [instream flow need]. ${ }^{\text {I }}$

It was not necessary to address and resolve the issue as part of the Horizon Project application. The position of AENV appeared to be based on the conditions in the licence and the belief that the conditions would permit Syncrude and others to be curtailed, if it was required to meet instream flow needs. It is not clear in the decision whether the Panel accepted AENV's submission. In any event, the position of AENV reflects a fundamental misunderstanding of the first in time, first in right system of water allocation. Syncrude, as the holder of a senior licence, is entitled to the benefit of the first in time, first in right principle. As a result, Syncrude would be able to insist that junior licensees be cut off prior to any reduction in Syncrude's allocation. Section 30(2) provides that a more senior licensee has the right to their whole allocation of water prior to a more junior licensee. The Director cannot curtail water allocations based on the desire to rateably allocate water when the Water Act specifically provides priority to the first licence holder. Ultimately, if the issue is forced, a prior licensee is entitled to its full allocation.

\section{Conclusion}

Fortunately, the oil and gas industry has not seen pervasive and acrimonious battles over access to water. Hopefully, the Water for Life Strategy and the growing recognition that water must be conserved will ensure that we never will. However, as we have discussed in this article, we have seen the first glimmers of what a full-scale competition for water may

Canadian Natural Resources Limiled, Application for Oll Sands Min. Bitumen Fixtraction Plant, and Bitumen Upgrading Plant in Fort McMurray Area (27 January 2004). AEUB Decision 2004-0005 al 40 (AEUB/CEEA Joint Review Panel). 
look like. The competition will arise on the issuance of new licences or between existing licence holders if the Director seeks to curtail allocations in times of scarcity. Ultimately, a successful application for a new water licence may depend on the approved water management plan for the particular water basin. As between holders of existing water licences, the competition for water will likely ultimately be resolved under the first in time, first in right principle. 